\title{
The rearing, growing and fattening performance, carcass and meat quality of pigs fed naked oats supplemented with enzymes
}

\author{
A. Milczarek ${ }^{1}$ and M. Osek \\ University of Podlasie, Chair of Animal Nutrition and Food Management \\ B. Prusa 14, 08-110 Siedlce, Poland
}

\begin{abstract}
Each of two diets containing 30\% naked oats, unsupplemented (diet I) or supplemented with a multienzyme preparation (diet II), was fed to 3 litters of piglets from the age of 10 days until weaning on day 52 (prestarter), to weaners until day 83 of life (grower), and to fatteners until slaughter on day 177 of life (grower and finisher). Thirty or thirty-one piglets and weaners and 20 fatteners were included in group I and II, respectively. Feeding diets supplemented with $\beta$-glucanase, hemicellulase, and pectinase increased daily gain from 251 to $266 \mathrm{~g}$ during the suckling period, and from 340 to $357 \mathrm{~g}$ from days 10 to 83 of life, and improved feed utilization in both periods compared with the control diet. Supplementation of naked oats with enzymes tended to improve fattening performance, significantly decreased loin eye area, and modified the fatty acid profile and water holding capacity of the loin, while increasing the dry matter content in ham. Feeding an enzyme-supplemented diet did not significantly affect sensory scores, but they tended to be lower in both ham and loin.
\end{abstract}

KEY WORDS: piglets, fatteners, performance, carcass, meat, naked oats, enzymes

\section{INTRODUCTION}

Naked oat grain is fed to pigs due to its favourable chemical composition and high energetic value in comparison with other grains (Brand and van der Merwe, 1996; Kosieradzka and Fabijańska, 1999; Fabijańska et al., 2003). The use of oats in diets for very young pigs is limited, however, because of its high $\beta$-glucan content (3-6\% of dry matter), which exceeds that in barley and husked oat (Bach Knudsen, 1993; Gibiński, 2000).

The aim of the study was to determine rearing, growing, fattening performance, and slaughter value in pigs fed an enzyme-supplemented diet containing naked oats.

\footnotetext{
${ }^{1}$ Corresponding author: e-mail: amilczarek@op.pl
} 


\section{MATERIAL AND METHODS}

The experiment involved feeding diets containing 30\% of naked oats (Table 1) unsupplemented (group I) or supplemented with a multienzyme preparation (group II) to piglets from day 10 day of age until weaning on day 52 (prestarter), from weaning to day 83 of life (grower), and day 83 until slaughter on day 177 of life (grower and finisher). The multienzyme preparation contained $\beta$-glucanase, hemicellulase, and pectinase and was fed at $1 \mathrm{~g} / \mathrm{kg}$ of the diet. Each group was issued from three litters of piglets of $\mathrm{LW} \times$ Puławska breed and comprised 30 and 31 piglets and weaners in groups I and II, respectively, and 20 fatteners (10 males and 10 females). The body weight of pigs on days 10, 52, 84 and 177 of life and feed intake were controlled. At the end of the fattening period, 10 animals from each group ( 5 males and 5 females) with a body weight similar to the group average were selected and slaughtered.

Table 1. Composition and nutritive value of mixtures

\begin{tabular}{|c|c|c|c|}
\hline \multirow{2}{*}{ Item } & \multicolumn{3}{|c|}{ Mixtures } \\
\hline & prestarter & grower & finisher \\
\hline \multicolumn{4}{|l|}{ Composition of diets, $\%$} \\
\hline wheat & 37 & - & - \\
\hline barley & - & 49 & 55 \\
\hline naked oats & 30 & 30 & 30 \\
\hline soyabean meal & 26 & 18 & 13 \\
\hline skim milk powder & 3 & - & - \\
\hline feed additives $^{1}$ & 4 & 3 & 2 \\
\hline \multicolumn{4}{|c|}{ Nutritive value per $1 \mathrm{~kg}$ of mixtures } \\
\hline crude protein, $\mathrm{g}$ & 219 & 175 & 159 \\
\hline crude fibre, $\mathrm{g}$ & 22.7 & 30.5 & 30.8 \\
\hline lysine, $g$ & 13.7 & 10.4 & 8.9 \\
\hline methionine + cystine, $\mathrm{g}$ & 7.9 & 6.4 & 6.0 \\
\hline threonine, $\mathrm{g}$ & 8.2 & 6.4 & 5.7 \\
\hline tryptophan, g & 2.6 & 2.1 & 1.9 \\
\hline metabolizable energy, MJ & 13.1 & 12.6 & 12.7 \\
\hline
\end{tabular}

${ }^{1}$ limestone, dicalcium phosphate, premix

Carcass leanness was estimated using an ULTRA-FOM 100 apparatus and $\mathrm{pH}_{45}$ was measured after slaughter, while $\mathrm{pH}_{24}$ and backfat thickness in 5 places were measured on cold carcasses after $24 \mathrm{~h}$. The chemical composition of loin and ham was determined according to AOAC (1990) and their fatty acid composition was determined as ethyl esters using gas chromatography. The water holding capacity was evaluated by the Grau and Hamm method (1953), and meat taste quality was estimated according to Baryłko-Pikielna (1975).

The results were analysed by one-factor analysis of variance and the significance of differences between means was determined by Student's t-test. 


\section{RESULTS AND DISCUSSION}

Feeding diets containing 30\% naked oats supplemented with a multienzyme preparation significantly increased the weight gains of piglets and improved feed utilization compared with the control diet in the periods from day 10 to 51 and from day 10 to 83 of age (Table 2). Weight gains after weaning (between days 52 and 83 of life) and during the fattening period (from days 84 to 177) also tended to be increased due to enzyme supplementation.

Table 2. Rearing, growing and fattening performance of pigs

\begin{tabular}{|c|c|c|c|}
\hline \multirow{2}{*}{ Item } & \multicolumn{2}{|c|}{ Groups } & \multirow{2}{*}{ SEM } \\
\hline & control & experimental & \\
\hline \multicolumn{4}{|l|}{ Rearing and growing performance } \\
\hline \multicolumn{4}{|l|}{ body weight, $\mathrm{kg}$} \\
\hline d 10 & 3.10 & 2.85 & 0.14 \\
\hline d 52 & $13.63^{*}$ & $14.02 *$ & 0.05 \\
\hline d 84 & $28.27 *$ & $29.29 *$ & 0.12 \\
\hline \multicolumn{4}{|l|}{ daily gain, $\mathrm{g}$} \\
\hline d $10-51$ & $251 *$ & $266^{*}$ & 1.43 \\
\hline d $52-83$ & 457 & 477 & 5.86 \\
\hline d $10-83$ & $340^{*}$ & $357^{*}$ & 1.96 \\
\hline \multicolumn{4}{|l|}{ Feed conversion ratio, g/kg gain } \\
\hline d $10-51$ & $438 *$ & $414^{*}$ & 2.68 \\
\hline d $52-83$ & 2230 & 2101 & 35.52 \\
\hline d $10-83$ & $1480 *$ & $1389 *$ & 17.76 \\
\hline \multicolumn{4}{|l|}{ Fattening performance } \\
\hline \multicolumn{4}{|l|}{ body weight, $\mathrm{kg}$} \\
\hline $\mathrm{d} 84$ & 28.75 & 28.70 & 0.45 \\
\hline d 177 & 97.30 & 98.70 & 0.56 \\
\hline daily gain, $\mathrm{g}$ & 737 & 753 & 1.15 \\
\hline feed conversion ratio, $\mathrm{kg} / \mathrm{kg}$ & 3.19 & 3.02 & - \\
\hline \multicolumn{4}{|l|}{ Carcass parameters } \\
\hline weight at slaughter, $\mathrm{kg}$ & 98.4 & 99.5 & 0.69 \\
\hline cold dressing percentage & 78.3 & 78.3 & 0.50 \\
\hline lean in carcass, $\%$ & 55.1 & 54.2 & 1.15 \\
\hline loin eye area, $\mathrm{cm}^{2}$ & $48.9^{*}$ & $45.4^{*}$ & 0.11 \\
\hline average backfat thickness, $\mathrm{mm}$ & 26.7 & 25.6 & 1.17 \\
\hline
\end{tabular}

* $-\mathrm{P} \leq 0.05$

The enzymes had no effect on carcass parameters except a decrease of loin eye area (Table 2), but affected the dry matter content in ham and the fatty acid profile and water holding capacity in loin (Table 3). The loin of pigs fed the enzyme-supplemented diet had a lower proportion of SFA and PUFA than the meat of control animals. 
The fattening performance of pigs fed on diets containing 30\% oats was lower in our experiment than reported by Kosieradzka and Fabijanska (1999), while the dressing percentage and loin area were higher.

Table 3. Physicochemical and sensory characteristics of meat

\begin{tabular}{|c|c|c|c|c|c|c|}
\hline \multirow{2}{*}{ Item } & \multicolumn{2}{|r|}{ Loin } & \multirow{2}{*}{ - SEM } & \multicolumn{2}{|r|}{ Ham } & \multirow{2}{*}{ SEM } \\
\hline & control & experimental & & control & experimental & \\
\hline \multicolumn{7}{|l|}{ Basic nutrients, \% } \\
\hline dry matter & 27.12 & 27.53 & 0.20 & $25.08^{*}$ & $26.04 *$ & 0.56 \\
\hline crude ash & 1.14 & 1.12 & 0.002 & 1.17 & 1.16 & 0.006 \\
\hline crude protein & 22.93 & 23.53 & 0.32 & 21.59 & 22.48 & 0.51 \\
\hline crude fat & 2.61 & 2.71 & 0.34 & 2.24 & 2.38 & 0.22 \\
\hline \multicolumn{7}{|l|}{ Fatty acids, \% total } \\
\hline SFA & $39.92 *$ & $38.55^{*}$ & 0.08 & 32.85 & 34.04 & 1.05 \\
\hline UFA & $59.92 *$ & $61.29 *$ & 0.11 & 66.97 & 65.78 & 0.98 \\
\hline MUFA & 54.74 & 56.48 & 0.48 & 56.47 & 55.49 & 1.26 \\
\hline PUFA & $5.18^{*}$ & $4.81 *$ & 0.05 & 10.50 & 10.29 & 1.11 \\
\hline $\mathrm{pH}_{45}$ & 6.07 & 6.22 & 0.13 & - & - & - \\
\hline $\mathrm{pH}_{24}$ & 5.84 & 5.82 & 0.10 & - & _ & - \\
\hline Water holding capacity, $\%$ & $20.71 * *$ & $22.13 * *$ & 0.08 & 21.60 & 20.53 & 0.41 \\
\hline Sensory scores (mean of traits, points) & 3.92 & 3.65 & 0.21 & 3.82 & 3.52 & 0.12 \\
\hline
\end{tabular}

* - $\mathrm{P} \leq 0.05 ; * *$ - $\mathrm{P} \leq 0.01$

\section{CONCLUSIONS}

A multienzyme preparation hydrolysing nonstarch polysaccharides may be recommended as a supplement improving the growth performance of young pigs fed on mixtures with naked oats.

\section{REFERENCES}

AOAC, 1990. Official Methods of Analysis, Association of Official Analytical Chemists. $15^{\text {th }}$ Edition. Washington, DC

Bach Kundsen K.E., 1993. Carbohydrates and lignin in feedstuffs. Proceedings of $44^{\text {th }}$ Annual Meeting of EAAP, Copenhagen (Denmark), pp. 1-10

Baryłko-Pikielna N., 1975. Outline of Sensory Analysis of Food (in Polish). WNT, Warszawa

Brand T.S., van der Merwe J.P., 1996. Naked oats (Avena nuda) as a substitute for maize in diets for weanling and grower-finisher pigs. Anim. Feed Sci. Tech. 57, 139-147

Gibiński M., 2000. Chemical composition of the selected varieties and strains of oat (in Polish). Food, Suppl. 2 (23) 84-91

Grau R., Hamm R., 1953. Über das Wasserbindugsvermögen des Säugetiermuskels. Z. Lebensm. Unters. Frosch. 105, 446-460

Fabijańska M., Kosieradzka I., Bekta M., 2003. Application of naked oats in feeding pigs and poultry. Part 1. Naked oats in feeding of fatteners. Biuletyn IHAR 229, pp. 317-328

Kosieradzka M., Fabijańska I., 1999. Polish naked oats in the intensive pig fattening (in Polish). XXVIII $^{\text {th }}$ Session of Animal Nutrition, Committee on Animal Sciences, Polish Academy of Sciences. "Nutritional Needs of High-Productive Farm Animals". Krynica (Poland), pp. 259-262 